Vol. 3 lists and describes a dozen new species of leaf-mining Diptera, and one new lepidopteran. It includes a list of the food plants, and of the families of insects involved. 170 pages contain 725 line drawings, mainly featuring the damage caused to plants by these insects. The figures are quite well drawn and reproduced.

These volumes will be a useful tool to agricultural entomologists and others, but it is a pity they could not have been produced more cheaply. The printing and paper are good but the books are poorly bound in flimsy paper covers. Notwithstanding the usefulness of the contents they seem expensive at eighteen pounds for the set of three modest volumes.

\section{KenNeth Mellanby}

\section{TRAINING MANAGERS}

\section{New Ways in Management Training}

A Technical College Develops its Services to Industry. By Cyril Sofer and Geoffrey Hutton. Pp. xii +127 . (London: Tavistock Publications, Ltd., 1958.) 15s. net.

YONCERN to make his department of more value 4 to industry in the training of managers led Robert Harcourt, head of the Department of Management and Production Engineering at the Brunel College of Technology, to initiate the study which is described in this book. The objects of the study were to examine the function and possibilities of a department of management and production engineering in servicing industry, how industry could make known its wants and needs as well as the way industry could help the department. The task was entrusted to the Tavistock Institute of Human Relations and, in collaboration with members of the Brunel College staff, was carried out during 1954-56.

While their report on this valuable investigation will be of interest to their fellow social scientists, Sofer and Hutton's account is likely to be of more direct value to training officers, educational administrators and many industrial managers. It will be of even greater relevance to those responsible for the control and development of technical colleges.

To set the study in its right background, an account is given of the place of the technical college in the national educational system and its place vis-à-vis the universities and other organizations in the training of management for industry. This is followed by details of the kinds of students who attend management courses at technical colleges, together with reasons as to why they attend. These are sometimes illuminating. Most of those who were studying for management certificates, for example, saw their courses as in some way a contribution to their personal advancement; most of the management, students expected to get better jobs with employers other than their own. Few students had really high ambitions and a not infrequent comment was : "I don't think I'll ever get to director level because you need social connections for that. Somebody who is likely to finish up at that level would not have come from a technical college, but would have taken a Cambridge degree".

One of the great weaknesses of technical college classes is borne out by the finding that most students did not expect to find discussions with fellow students very helpful to learning. Each student's contact with others was said to be minimal : "Hardly any friend- ships were developed within the class and very little discussion of course material took place spontaneously. ... At the end of the evening everybody went home-they were tired and hungry".

The attitudes of firms in Acton to technical colleges and their staffs can be regarded as typical for the whole of Great Britain. Although educational and scientific pursuits rank fairly high as social activities in Britain, the status of technical colleges among them is low ; they are thought to serve a less-important purpose than more 'academic' institutions, and to be concerned more with training in specific craft skills than with the preparation of young people for life or for positions of social leadership and responsibility. Teachers in technical colleges are regarded more as school teachers than university lecturers, and as persons of mediocre calibre. The technical college teacher was thought to be insufficiently appreciative of production management, 'up in the air' and overtheoretical ; it was often said that a man who really knew management and could practise what he preached would be a manager, not a teacher. Larger firms felt no need for the services of management and production engineering departments except for a limited amount of junior supervisory classes and for management courses of the conventional type; smaller firms made demands for courses in the organization and supervision of production and in general education.

The rest of the book describes how Sofer and Hutton and their collaborators attempted to find a way through this wall of prejudice. After considerable resentment had been dissipated, the teachers began to understand that the views of the industrialists were not wholly distorted; the industrialists began to realize that under their noses was a most valuable service if they cared to use and contribute to it. Detailed surveys were carried out in firms to show how the department could be of greater value to them and, eventually, separate advisory panels were formed to make a permanent link between the College and industry. Finally, members of the Tavistock Institute of Human Relations were asked to organize a course to help the teachers to become more expert in dealing with students from industry and industrial affairs. It needs little reading between the lines to appreciate that this was far from successful and that the approach of the academic social scientist in teaching teachers has considerable limitations.

Of the study as a whole, not much need be written. Harcourt and all those concerned at the Brunel College of Technology deserve applause for their courage and perspicacity in initiating the project. The Tavistock Institute of Human Relations should be congratulated for the way it saw and grasped an opportunity to improve the quality of management education at Acton and elsewhere. Sofer and Hutton are to be warmly commended for carrying out a difficult survey in an objective and discerning manner and for recording it so intelligibly. This is so out of keeping with other publications of the Tavistock Institute that it scarcely seems possible that this book could have been produced under its auspices. By this important work Sofer and Hutton have not only made a contribution to the development of better management education at technical colleges, but may also have reconverted leading industrialists to the belief that the Tavistock Institute really has a contribution to make to the solution of many industrial problems.

T. H. HaWkINS 